\title{
Synthesis, Characterization and DFT-Based Investigation of a Novel Trinuclear Singly-Chloro-Bridged Copper(II)-1-Vinylimidazole Complex
}

\author{
Zuhal Yolcu, ${ }^{1, *}$ Serkan Demir, ${ }^{2}$ Ömer Andaç, ${ }^{3}$ and Orhan Büyükgüngör ${ }^{4}$ \\ ${ }^{1}$ Department of Chemistry, Faculty of Art and Science, Giresun University, Giresun, Turkey \\ ${ }^{2}$ Department of Industrial Engineering, Faculty of Engineering, Giresun University, Giresun, Turkey \\ ${ }^{3}$ Department of Chemistry, Faculty of Art and Science, Ondokuz Mayýs University, Atakum, Samsun, Turkey \\ ${ }^{4}$ Department of Physics, Faculty of Art and Science, Ondokuz, Mayýs University, Atakum, Samsun, Turkey \\ * Corresponding author: E-mail: zuhal.yolcu@giresun.edu.tr
}

Received: 31-03-2016

\begin{abstract}
A novel trinuclear copper(II) complex $\left[\mathrm{Cu}_{3}(\mu-\mathrm{Cl})_{2} \mathrm{Cl}_{4}(1-\mathrm{Vim})_{6}\right]$ with monodentate 1-vinylimidazole (1-Vim) and chloro ligands has been prepared and experimentally characterized by elemental analysis, thermogravimetry (TGA, DTG, DTA), X-ray single crystal diffractometry, TOF-MS and FT-IR spectroscopies. The electronic and structural properties of the complex were further investigated by DFT/TD-DFT methods. Density functional hybrid method (B3LYP) was applied throughout the calculations. The calculated UV-Vis results based on TD-DFT approach were simulated and compared with experimental spectrum. Based on the data obtained, DFT calculations have been found in reasonable accordance with experimental data.
\end{abstract}

Keywords: 1-vinylimidazole, trinuclear copper(II), singly-chloro-bridged, DFT/TD-DFT

\section{Introduction}

Molecular behaviours of polynuclear transition metal complexes have been an indispensable subject of numerious researches in coordination chemistry because of their multifarious electronic, magnetic and optical properties. ${ }^{1-3}$ These prominent features essentially stem from the existence and the adjacent positions of two or more metallic centers in the same molecular unit. Among these, polynuclear copper(II) species ${ }^{4-8}$ are the most intriguing and investigated ones due to their plain structural properties, ability to mimic active sites in certain copper containing proteins and easy to rationalize and diverse magnetic properties as the simplest examples of magnetic exchange interactions. ${ }^{9-14}$ From another standpoint, the selection or design of the organic ligands are of cruical importance on self-assembly of metal ions owing to their requisite functional roles as transmitters of close metalmetal communications other than they are the backbones of these polynuclear aggregates. ${ }^{15-17}$ Generally, the use of polydentate ligands that can present different coordination behaviours according to nature of the metal ions is straightforward for aforementioned versatilities. In case of our study reported herein, a novel mono-chloro-bridged trinuclear complex consisting of two discrete metal(II) centers connected through simple bridging chloro ligands and coordinated with monodentate 1-vinylimidazole ligands and monodentate chloro ligands were prepared and fully characterized. The interesting topology of the the complex was probed with X-ray single-crystal data. Qualitative picture of spectroscopic and structural properties of the complex beyond the experimental data were further investigated in the framework of density functional theory (DFT) and its time-dependent extension (TD-DFT). It is well known from the literature that DFT methods, especially the latter introduced hybrid ones that predict almost all molecular properties from simple organic molecules to more complex systems such as transition metal complexes are superior to other wave-function based electron correlation methods in preference. This is 
first because they present same or near accuracy results and second, require much more affordable computation time compared to other multi-determinantal approaches that are still applicable only to small/moderate molecules within current computational facilities. ${ }^{18-20}$

\section{Experimental}

\section{1. Synthesis of the Complex}

$0.855 \mathrm{~g}$ (5.00 mmol) $\mathrm{CuCl}_{2} \cdot 2 \mathrm{H}_{2} \mathrm{O}$ was dissolved in $40 \mathrm{~mL}$ of water:ethanol $(3: 1)$ mixture and to this solution which was heated up to $70{ }^{\circ} \mathrm{C}, 0.941 \mathrm{~g}(10.0 \mathrm{mmol})$ of 1 -vinylimidazole was gradually added with constant stirring at the same temperature. The obtained mixture was stirred for half a hour, filtered off and left undisturbed for crystallization. After 30 days needle-shaped dark green crystals of X-ray quality were obtained from the solution. Yield: 48\%. Anal. Cacld.(\%): C 37.21, N 17.36, H 3.72. Found: $\mathrm{C} 37.12, \mathrm{~N} 16.82, \mathrm{H}$ 3.25. $\mathrm{IR}\left(\mathrm{KBr}, \mathrm{cm}^{-1}\right)$ : 3143-3117, $v(\mathrm{C}-\mathrm{H})_{\text {vinyl }} ; 3023, \quad \mathrm{v}(\mathrm{C}-\mathrm{H})_{\text {arom. }} ; 1645$, $v(C=C) ; 1503, v(C=N)$ (See Figure $S 1$ in supporting information).

\section{2. Physical Measurements}

All the reactants and solvents were obtained from commercial suppliers and used without further purification. FT-IR spectrum was recorded on a BRUKER 2000 spectrometer as $\mathrm{KBr}$ slice. UV-Vis spectrum was measured with a UNICAM UV2 spectrometer in 200-800 nm range in methanolic solution. ESI mass spectrum was recorded with Agilent LC/MS-TOF spectrometer using methanolic solution. Elemental analysis was performed with a Costech ECS 4010 CHNS Elemental analyzer. Simultaneous thermal analyses were conducted by using a SIIOExstar 6000 Thermal analyzer within $35-1000{ }^{\circ} \mathrm{C}$ temperature range, by a heating rate of $10^{\circ} \mathrm{C} / \mathrm{min}$. and in static nitrogen atmosphere.

Intensity data were collected using a STOE IPDS 2 diffractometer with graphite monochromated Mo $\mathrm{K}_{\alpha}$ radiation $(\lambda=0.71073 \AA)$ at $293(2) \mathrm{K}$. The structure was solved by direct methods ${ }^{21}$ and refined with full-matrix least-squares procedure on $F^{2}$ using SHELXL97. ${ }^{22}$ All non-hydrogen atoms were refined anisotropically. Hydrogens bonded to carbon atoms were positioned geometrically and refined with a riding model with $U_{\text {iso }} 1.2$ times that of attached carbon atoms. The positions of water hydrogens were found by difference fourier map and refined isotropically.

\section{3. Computational Procedure}

All computations reported herein were carried out using Gaussian $03 \mathrm{~W}$ suit of program ${ }^{23}$ under $\mathrm{C}_{\mathrm{i}}$ constrained symmetry within unrestricted formalism. Spin-doub- let gas-phase B3LYP optimizations of the complex starting from experimental X-ray geometry was performed employing triple-zeta 6-311G(d) basis set for $\mathrm{Cu}$ atoms, double-zeta 6-31G(d) basis set for $\mathrm{H}, \mathrm{C}$ and $\mathrm{N}$ atoms and 6-31G+(d) basis set for more diffuse chlorine atoms. Vibrational frequency analysis was calculated at the optimized structure at the same level of theory to ensure that the final geometry is a local minimum having no imaginary frequency.

TD-DFT excited state calculation was performed at the geometry optimized structure using the flexible LANL2DZ basis set for all atoms considering the large size of the system.

Investigation of natural charge distributions, population analysis of valence core orbitals and non-covalent energetic stabilizations by second order perturbation theory analysis of Fock matrix were carried out using natural bond orbital (NBO) analysis at the UB3LYP optimized structure by NBO version 3.1 implemented in Gaussian $03 \mathrm{~W}$ package.

The percentage molecular orbital contributions (MOCs) from atoms and groups to the related molecular orbitals (MOs), were extracted from single point energy (SPE) calculation of the optimized structure using $V M O$ des software. ${ }^{24}$

\section{Results and Discussion}

\section{1. Crystal Structure}

A perspective plot with the atom numbering scheme of the complex is shown in Figure 1 and the crystallographic data are given in Table 1 . The crystal consists of neutral trimeric units and the symmetric unit of the network consists of two geometrically different copper(II) centers one of which $\left(\mathrm{Cu} 2\right.$ and $\left.\mathrm{Cu} 2^{\mathrm{i}} \mathrm{i}: 1-x,-y, 1-z\right)$ is distorted square-pyramidal and the other $(\mathrm{Cu} 1)$ is distorted squareplanar geometry as shown in Figure 2. In the trimer unit, the central copper(II) ion located on inversion center possessing a quasi-octahedral coordination geometry in which the two singly-bridging chloro ligands $\left(\mathrm{Cl1}, \mathrm{Cl1}^{\mathrm{i}}\right)$ together with two $\mathrm{N}$ atoms $\left(\mathrm{N} 1, \mathrm{~N} 1^{\mathrm{i}}\right)$ of monodentate 1vim molecules are located on square plane. The two monodentate chloro ligands $\left(\mathrm{Cl} 2, \mathrm{Cl} 2^{\mathrm{i}}\right)$ weakly coordinated and reside in the apical positions. Symmetry related copper(II) terminal has more common penta-coordination with the two monodentate chloro ligands $(\mathrm{Cl} 2, \mathrm{Cl} 3)$, two $\mathrm{N}$ atoms (N3, N5) of 1-vim molecules of basal plane and one axially coordinated mono-bridging chloro ligand (C11). The coordination number 5 for copper(II) ions usually presents either a square pyramidal (SP) or trigonalbipyramidal (TBP) geometry (or an intermediate geometry). The Addison distortion index, $\tau$ used for the evaluation of the distortion of coordination geometry from TBP to SP was calculated as 0.187 and clearly suggests a distorted SP extreme for terminal copper(II) ions in the tri- 
mer unit ${ }^{25,26}$ ( $\tau=\alpha-\beta / 60$, where $\alpha$ and $\beta$ correspond to two angles showing tendency to linearity). The $\tau$-values of square-based-pyramidal and trigonal-bipyramidal extremes are 0 and 1, respectively. ${ }^{27}$ In one aspect, as the quasioctahedral geometry of $\mathrm{Cu} 1$ ion is considered, the long

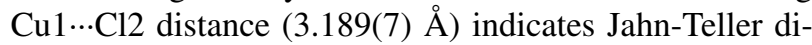
stortion by elongation through coordination of chlorine linkers to terminal copper(II) ions. But in another, bond valence analysis ${ }^{28,29}$ more clearly substantiates the preponderance of square-planar geometry. In basal plane, Cu2-Cl2 distance $(2.339$ (7) $\AA$ ) is longer than that of $\mathrm{Cu} 2-\mathrm{Cl} 3(2.299(7) \AA)$ and approves the weak coordination of $\mathrm{Cl} 2$ ligand to the central copper(II) ion to form a quasi-octahedron around $\mathrm{Cu} 1$. The terminal copper(II) ions displaces $0.131 \AA$ from the basal plane upon coordination to bridging chloride ions.

The two mono-bridging chloro ligands bond in apical position to the terminal copper(II) ions and in equatorial position to the central copper(II) ion. Through these connections, copper(II) centers are arranged in a zig-zag fashion in the trimer. The bridging bond lengths $\mathrm{Cu} 1-\mathrm{Cl} 1$ and $\mathrm{Cu} 2-\mathrm{Cl} 1$ are 2.315(7) $\AA$ and 2.825(8) $\AA$, respectively, while corresponding bridging angle $\mathrm{Cu} 1-\mathrm{Cl} 1-\mathrm{Cu} 2$ is $101.92(2)^{\circ}$. The small bridging angle gives rise to a shorter $\mathrm{Cu} 1-\mathrm{Cu} 2$ seperation $(4.005 \AA)$ and probably to the formation of a monomeric structure rather than a polymeric one as compared to the similiar molecular structure repor-

Table 1. Crystallographic data for $\left[\mathrm{Cu}_{3}(\mu-\mathrm{Cl})_{2} \mathrm{Cl}_{4}(1-\mathrm{Vim})_{6}\right]$

\begin{tabular}{ll}
\hline Chemical formula & $\mathrm{C}_{30} \mathrm{H}_{36} \mathrm{Cl}_{6} \mathrm{~N}_{12} \mathrm{Cu}_{3}$ \\
Formula weight & 968.03 \\
Temperature $(\mathrm{K})$ & $293(2) \mathrm{K}$ \\
Wave length $(\AA)$ & $0.71073 \AA$ \\
Crystal class & Triclinic \\
Space group & $P-1$ \\
Unit cell dimensions & \\
$a(\AA)$ & $8.7544(8)$ \\
$b(\AA)$ & $11.0084(10)$ \\
$c(\AA)$ & $11.8464(10)$ \\
$\alpha$ & $62.551(6)$ \\
$\beta$ & $70.781(7)$ \\
$\gamma$ & $70.947(7)$ \\
$V\left(\AA^{3}\right)$ & $935.65(14)$ \\
$Z$ & 1 \\
Density calculated $\left(\mathrm{mg} / \mathrm{m}^{3}\right)$ & 1.718 \\
Absorption coefficient $\left(\mathrm{mm}{ }^{-1}\right)$ & 2.16 \\
$F(000)$ & 489 \\
Reflections collected & 7572 \\
Independent reflections & $4571[\mathrm{R}(\mathrm{int})=0.0375]$ \\
Reflections measured $(>2 \sigma)$ & 3724 \\
GOF & 1.056 \\
final $R$ indices $[\mathrm{I}>2 \sigma(\mathrm{I})]$ & $\mathrm{R} 1=0.0348, \mathrm{wR} 2=0.0858$ \\
& $($ all data) \\
& $\mathrm{R} 1=0.0306, \mathrm{wR} 2=0.0806$ \\
Largest difference peak and & 0.281 and -0.598 \\
hole $\left(\mathrm{e} \AA^{-3}\right)$ & \\
\hline &
\end{tabular}

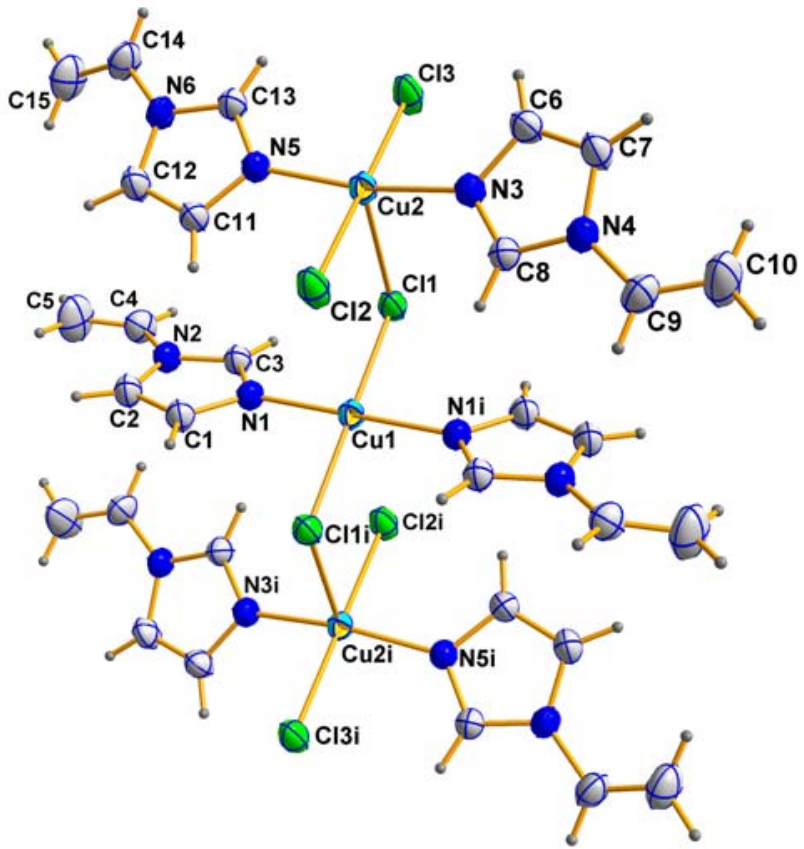

Figure 1. Molecular structure of $\left[\mathrm{Cu}_{3}(\mu-\mathrm{Cl})_{2} \mathrm{Cl}_{4}(1-\mathrm{Vim})_{6}\right]$ with atom labeling scheme.

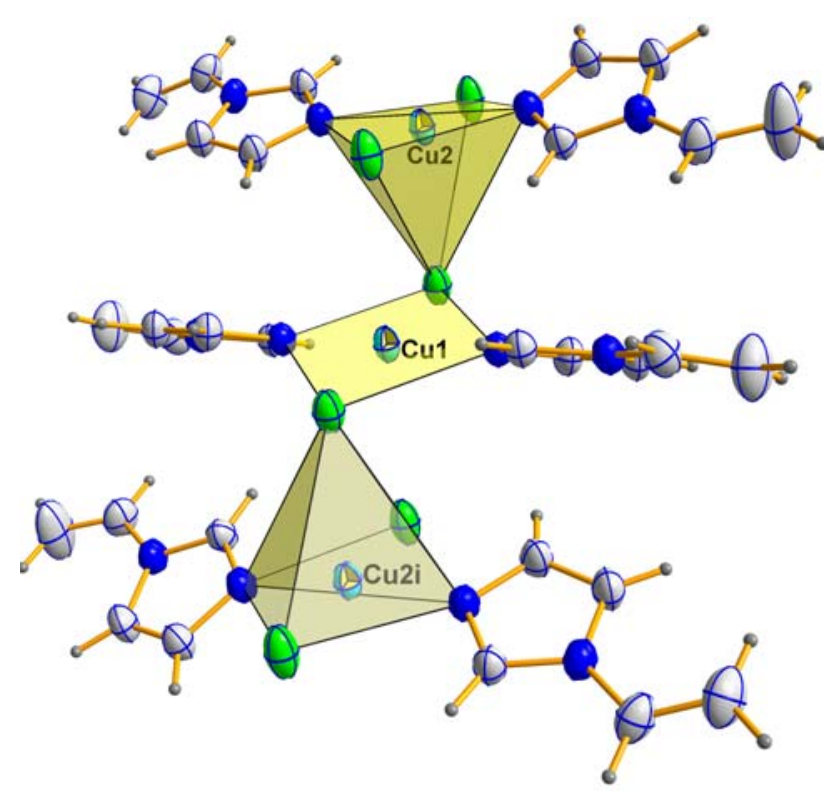

Figure 2. Two different coordination polyhedra around two different copper(II) centers

ted by Ray et al..$^{30}$ This type of copper(II) complexes incorporating only one bridging-chloro ligands are not common and hence are of special interest. ${ }^{3-33}$ None of intramolecular $\mathrm{H}$-bonds were detected in the trimer. But the weak intermolecular non-classical $\mathrm{C} 12-\mathrm{H} 12 \cdots \mathrm{Cl} 3(x-1$, $y,-z)$ interactions together with $\mathrm{C} 4-\mathrm{H} 4 \cdots \mathrm{Cg} 1(x, 1+y, z)$ $3.00 \AA, \mathrm{C} 8-\mathrm{H} 8 \cdots \mathrm{Cg} 22.81 \AA$ and $\mathrm{C} 11-\mathrm{H} 11 \cdots \mathrm{Cg} 2(1-x$, 


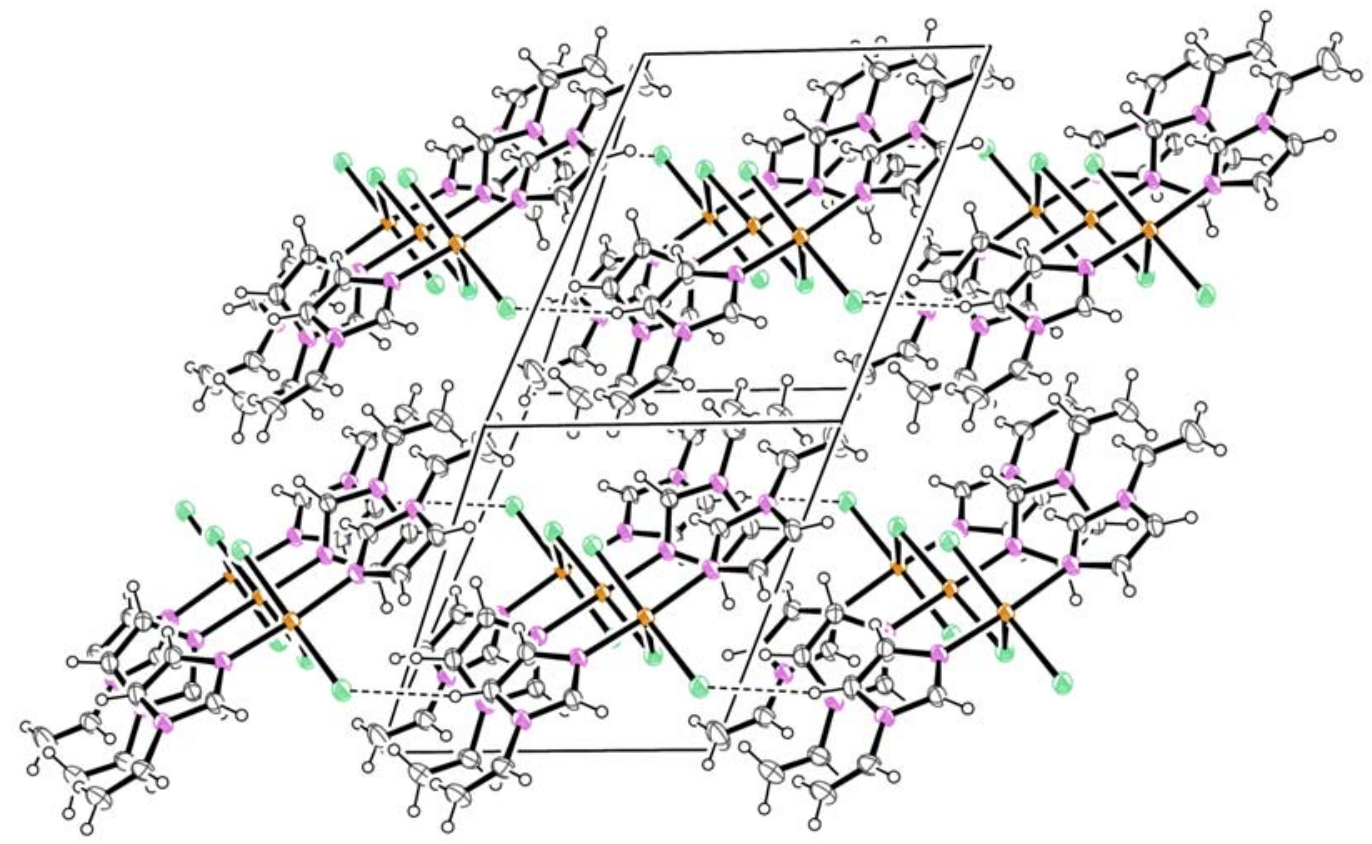

Figure 3. Crystal packing diagram of $\left[\mathrm{Cu}_{3}(\mu-\mathrm{Cl})_{2} \mathrm{Cl}_{4}(1-\mathrm{Vim})_{6}\right]$ down to c-axis

$-y, 1-z) 2.69 \AA$ stacking interaction propagate the molecule along the c-axis as shown in crystal packing diagram in Figure 3.

\section{2. TOF-MS Spectroscopy}

Successive MS measurements of the compound sample demonstrated almost same fragmentation products. The most abundant signal at $\mathrm{m} / \mathrm{z}=991.5$ [Na+complex] in TOF-MS spectrum of the complex in Figure 4 is related to sodiated adduct of the trinuclear structure since the spectrum was taken in positive ion mode. Designation of other significant peaks is not possible due to probably different stable adducts and fragments in solution medium. Nevertheless, the expected sodium adduct of the complex is the most abundant one among them (Figure 4).

\section{3. Thermogravimetry}

The thermogram of the complex comprising simultaneous TG and DTA curves is depicted in Figure 5. Endothermic DTA signal observed immediate before decomposition onset denotes to melting phenomenon at c.a 137 ${ }^{\circ} \mathrm{C}$. After the completion of the melting, the ligands endothermically release between $146-262{ }^{\circ} \mathrm{C}$ and $262-932{ }^{\circ} \mathrm{C}$. The mismatch between the observed $(84.20 \%)$ and calculated $(75.36 \%$ for $\mathrm{CuO}$ final product, and $80.33 \%$ for $\mathrm{Cu}$ residue) total mass losses is only attributable to additional carbon remains with either two final products.

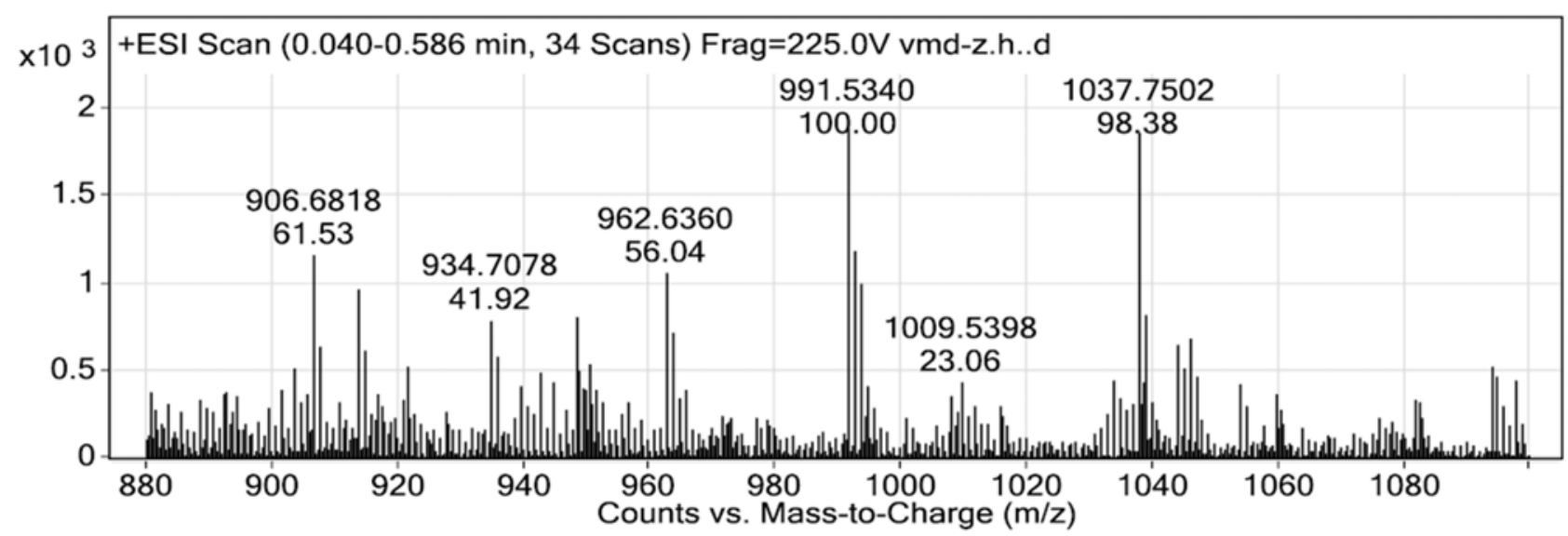

Figure 4. TOF-MS spectrum of $\left[\mathrm{Cu}_{3}(\mu-\mathrm{Cl})_{2} \mathrm{Cl}_{4}(1-\mathrm{Vim})_{6}\right]$ 


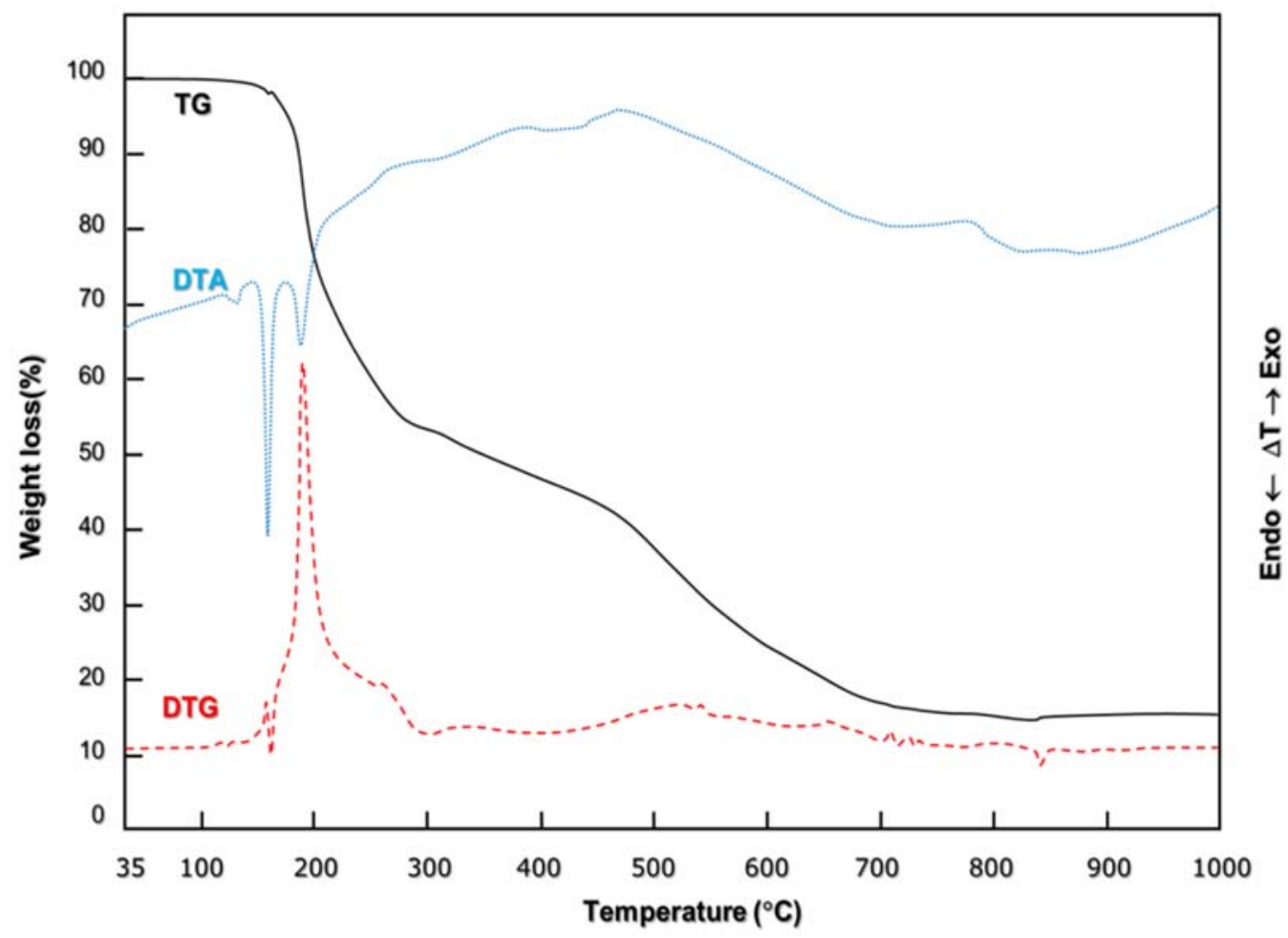

Figure 5. Simultaneous TG, DTG and DTA curves of $\left[\mathrm{Cu}_{3}(\mu-\mathrm{Cl})_{2} \mathrm{Cl}_{4}(1-\mathrm{Vim})_{6}\right]$

\section{4. Geometry Optimization}

The ground state geometry of the complex was optimized on spin unrestricted doublet state applying tight SCF procedure. The main geometrical parameters related to optimized structure are listed in Table 2 together with experimental ones. Calculated MOCs from atoms and group were given in Table 3 and frontier molecular orbitals were depicted in Figure 6. The calculated SOMO (singly occupied molecular orbital (from unrestricted

Table 2. Selected experimental and calculated bond lengths and angles of $\left[\mathrm{Cu}_{3}\left(\mu-\mathrm{Cl}_{2} \mathrm{Cl}_{4}(1-\mathrm{Vim})_{6}\right]\right.$

\begin{tabular}{|c|c|c|c|c|c|}
\hline \multicolumn{3}{|c|}{ Bond lengths (ঐ) } & \multicolumn{3}{|c|}{ Bond angles $\left(^{\circ}\right)$} \\
\hline Bond & Exp. & Calc. & Angle & Exp. & Calc. \\
\hline$\overline{\mathrm{Cu} 1-\mathrm{Cu} 2 *}$ & 4.005 & 4.078 & $\mathrm{~N} 1-\mathrm{Cu} 1-\mathrm{Cl} 1$ & $90.14(5)$ & 90.21 \\
\hline $\mathrm{Cu} 1-\mathrm{Cl1}$ & $2.315(7)$ & 2.445 & $\mathrm{~N} 1{ }^{\mathrm{i}}-\mathrm{Cu} 1-\mathrm{Cl} 1$ & $89.86(5)$ & 89.79 \\
\hline $\mathrm{Cu} 1-\mathrm{N} 1$ & $1.978(16)$ & 1.972 & $\mathrm{~N} 1-\mathrm{Cu} 1-\mathrm{Cl} 2$ & $88.75(5)$ & 85.85 \\
\hline $\mathrm{Cu} 1-\mathrm{Cl} 2$ & $3.189(7)$ & 3.193 & $\mathrm{~N} 1{ }^{\mathrm{i}}-\mathrm{Cu} 1-\mathrm{Cl} 2$ & $91.25(5)$ & 94.15 \\
\hline $\mathrm{Cu} 2-\mathrm{Cl} 2$ & $2.339(7)$ & 2.449 & $\mathrm{Cl} 1-\mathrm{Cu} 1-\mathrm{Cl} 2$ & $79.35(3)$ & 81.75 \\
\hline $\mathrm{Cu} 2-\mathrm{Cl} 3$ & $2.299(7)$ & 2.405 & $\mathrm{Cl} 1-\mathrm{Cu} 1-\mathrm{Cl} 2^{\mathrm{i}}$ & $100.64(2)$ & 98.25 \\
\hline $\mathrm{Cu} 2-\mathrm{N} 3$ & $1.993(17)$ & 1.979 & $\mathrm{Cu} 1-\mathrm{Cl} 1-\mathrm{Cu} 2$ & $101.92(2)$ & 98.70 \\
\hline $\mathrm{Cu} 2-\mathrm{N} 5$ & $1.990(17)$ & 1.987 & $\mathrm{Cu} 1-\mathrm{Cl} 2-\mathrm{Cu} 2$ & $91.53(2)$ & 91.61 \\
\hline \multirow[t]{8}{*}{$\mathrm{Cu} 2-\mathrm{Cl} 1$} & $2.825(8)$ & 2.915 & N3-Cu2-N5 & $166.92(7)$ & 178.43 \\
\hline & & & $\mathrm{N} 3-\mathrm{Cu} 2-\mathrm{Cl} 2$ & $89.84(5)$ & 89.75 \\
\hline & & & $\mathrm{N} 3-\mathrm{Cu} 2-\mathrm{Cl} 3$ & $89.41(5)$ & 88.98 \\
\hline & & & $\mathrm{N} 3-\mathrm{Cu} 2-\mathrm{Cl} 1$ & $96.59(5)$ & 90.19 \\
\hline & & & $\mathrm{N} 5-\mathrm{Cu} 2-\mathrm{Cl} 2$ & $90.40(5)$ & 90.93 \\
\hline & & & $\mathrm{N} 5-\mathrm{Cu} 2-\mathrm{Cl} 3$ & $89.95(5$ & 90.03 \\
\hline & & & $\mathrm{N} 5-\mathrm{Cu} 2-\mathrm{Cl} 1$ & $96.48(5)$ & 91.25 \\
\hline & & & $\mathrm{Cl} 1-\mathrm{Cu} 2-\mathrm{Cl} 2$ & $87.19(2)$ & 87.75 \\
\hline
\end{tabular}

i: $1-x,-y, 1-z$

*: The $\mathrm{Cu} 1 \cdots \mathrm{Cu} 2$ seperation being rather than a bond is given together with other important geometrical parameters for uniformity of the data. 
Table 3. Calculated MOCs from atoms and groups

\begin{tabular}{|c|c|c|c|c|c|c|c|c|c|c|c|c|}
\hline \multirow{2}{*}{ MO } & \multirow{2}{*}{$\mathbf{S}(\boldsymbol{\alpha})$} & \multicolumn{2}{|c|}{ H } & \multicolumn{2}{|c|}{ H-1 } & \multicolumn{2}{|c|}{ H-2 } & \multirow{2}{*}{$\begin{array}{r}\mathbf{L} \\
\boldsymbol{\beta}\end{array}$} & \multicolumn{2}{|c|}{$\mathrm{L}+1$} & \multicolumn{2}{|c|}{$\mathrm{L}+2$} \\
\hline & & $\alpha$ & $\beta$ & $\alpha$ & $\beta$ & $\alpha$ & $\beta$ & & $\alpha$ & $\beta$ & $\alpha$ & $\beta$ \\
\hline$\overline{E(e V)}$ & $\begin{array}{l}-6.03 \\
\end{array}$ & 6.070 & 6.038 & -6.147 & 6.83 & 6.164 & 6.108 & 2.786 & 2.898 & 2.785 & 1.350 & 1.351 \\
\hline $\mathrm{Cu} 1$ & 0.7 & 0.0 & 3.0 & 2.6 & 0.0 & 0.0 & 6.6 & 0.0 & 54.9 & 0.0 & 0.1 & 0.1 \\
\hline $\mathrm{Cu} 2$ & 8.5 & 9.6 & 3.0 & 2.5 & 3.2 & 2.6 & 1.9 & 25.9 & 0.0 & 26.6 & 0.0 & 0.0 \\
\hline $\mathrm{Cl} 1$ & 3.8 & 0.6 & 7.2 & 3.8 & 7.8 & 15.7 & 21.5 & 0.2 & 11.0 & 0.1 & 0.1 & 0.1 \\
\hline $\mathrm{Cl} 2$ & 15.2 & 11.8 & 2.8 & 6.5 & 2.8 & 7.7 & 15.2 & 4.7 & 0.1 & 5.2 & 0.1 & 0.1 \\
\hline $\mathrm{Cl} 3$ & 11.3 & 12.3 & 31.3 & 31.1 & 32.1 & 19.0 & 3.1 & 5.8 & 0.1 & 6.3 & 0.0 & 0.0 \\
\hline 1-Vim(1) & 0.2 & 0.1 & 1.1 & 0.3 & 0.5 & 0.7 & 3.0 & 0.0 & 9.0 & 0.4 & 13.4 & 13.5 \\
\hline 1-Vim(2) & 5.0 & 6.3 & 0.9 & 1.5 & 1.2 & 1.7 & 0.4 & 4.6 & 0.3 & 4.7 & 3.2 & 3.1 \\
\hline 1-Vim(3) & 4.7 & 5.8 & 1.0 & 1.6 & 1.0 & 1.6 & 0.7 & 4.4 & 0.2 & 4.6 & 3.1 & 3.0 \\
\hline
\end{tabular}

S, SOMO; H, HOMO; H-1, HOMO-1, etc. L, LUMO; L+1, LUMO+1, etc. the numbering of 1-Vim molecules was made by concerning preceding number of atoms involved $\alpha$ spin LUMO is considered as SOMO and so not given in the table again

doublet calculation))-LUMO gap is $3.132 \mathrm{eV}$. Of the distributions of MOs, $\beta$-spin LUMO and LUMO+1 are mainly localized on copper(II) ions (\%51.8 for $\beta$-LUMO and $\% 53.2$ for $\beta$-LUMO+1) while $\alpha$-spin LUMO is composed mainly of central copper(II) ion (\%54.9). The very low contributions from metal ions to occupied MOs indirectly drawn attention to a predominant coulombic interaction between metal centers and coordinated atoms. Superimposition of experimental and gas-phase optimized structures was presented in Figure 7. In general, there is a pleasant consistence between optimized and X-ray geometries according to the results and as expected, the general tendency of gas-phase optimizations in favour of somewhat extending the bond distances was introduced.
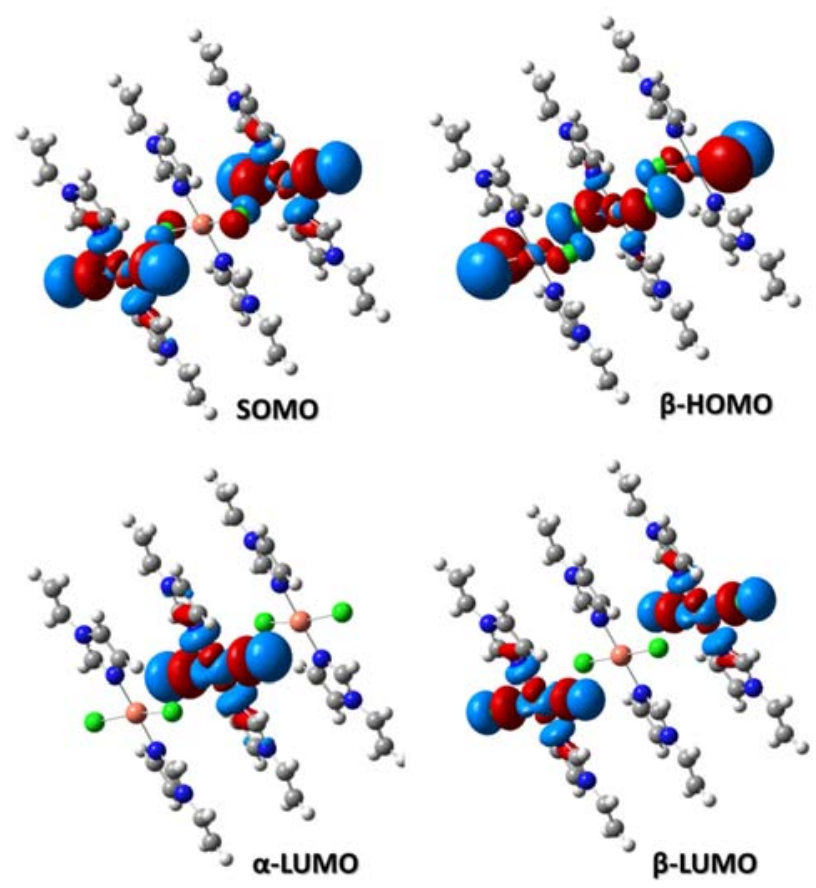

Figure 6. Frontier Molecular orbitals of $\left[\mathrm{Cu}_{3}(\mu-\mathrm{Cl})_{2} \mathrm{Cl}_{4}(1-\mathrm{Vim})_{6}\right]$

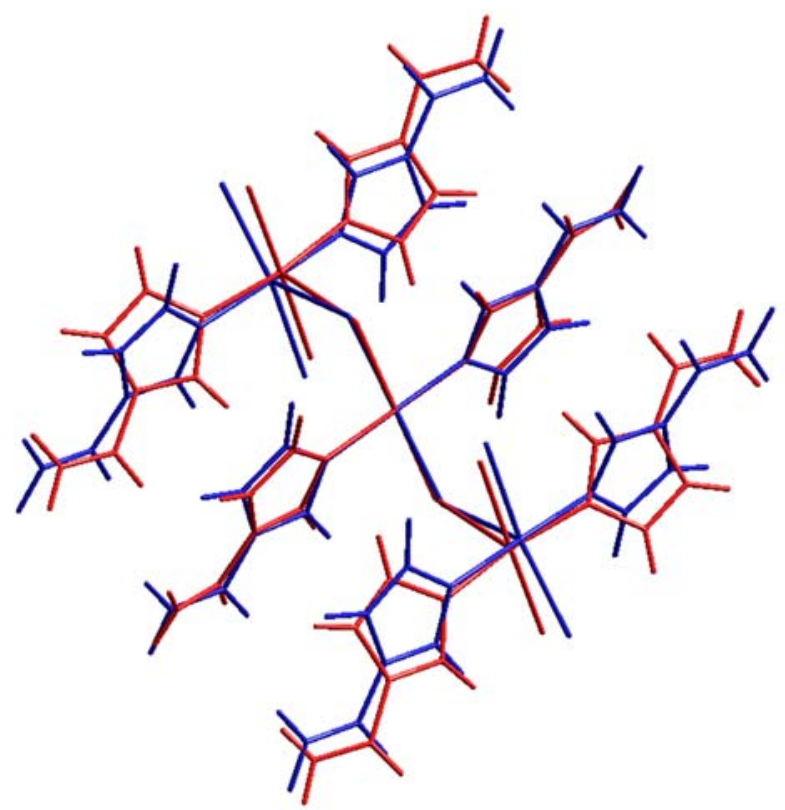

Figure 7. Superimposition of the $\mathrm{X}$-ray (red) and Optimized (blue) geometries of $\left[\mathrm{Cu}_{3}(\mu-\mathrm{Cl})_{2} \mathrm{Cl}_{4}(1-\mathrm{Vim})_{6}\right]$

\section{5. NBO Analysis and TD-DFT Calculation}

Valence core electron populations of the molecule are presented in Table 4 . The calculated charges of central metal ions are 0.66 and 0.70 respectively and lower than the oxidation state +2 and indicates the total charge donations from ligands to $\mathrm{Cu} 1$ and $\mathrm{Cu} 2$ ions equals. The nearest $\mathrm{Cl} 3$ atom to metal ion hold the least negative charges $(-0.74)$ as expected. The bridging $\mathrm{Cl} 1$ and so-called monodentate $\mathrm{Cl} 2$ have almost even charges due to their similiar positions between two metals. Consequently, the natural charges of the ligands and metals are comparatively expedient to their corresponding distances among each other. 
Table 4. Valence core electron populations from NBO analysis

\begin{tabular}{|c|c|c|c|c|c|c|c|c|c|}
\hline & $\begin{array}{l}\text { Atom } \\
\text { Charge }\end{array}$ & $\begin{array}{l}\text { Cu1 } \\
1.34\end{array}$ & $\begin{array}{l}\mathrm{Cu2} \\
1.30\end{array}$ & $\begin{array}{c}\text { Cl1 } \\
-0.75\end{array}$ & $\begin{array}{c}\mathrm{Cl} 2 \\
-0.74\end{array}$ & $\begin{array}{c}\mathrm{Cl3} \\
-0.77\end{array}$ & $\begin{array}{c}\text { N1 } \\
-0.63\end{array}$ & $\begin{array}{c}\mathbf{N 3} \\
-0.63\end{array}$ & $\begin{array}{c}\mathbf{N 5} \\
-0.62\end{array}$ \\
\hline \multirow{11}{*}{ 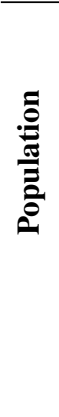 } & $2 s$ & - & - & - & - & - & 1.37 & 1.38 & 1.37 \\
\hline & $3 s$ & - & - & 1.97 & 1.98 & 1.97 & - & - & - \\
\hline & $2 p$ & - & - & 6.00 & 6.00 & 6.00 & 4.20 & 4.23 & 4.22 \\
\hline & 3p(total) & 6.00 & 6.00 & 5.78 & 5.76 & 5.79 & - & - & - \\
\hline & $3 d x y$ & 1.88 & 1.86 & - & - & - & & - & - \\
\hline & $3 \mathrm{dxz}$ & 1.98 & 1.98 & - & - & - & & - & - \\
\hline & $3 d y z$ & 1.69 & 1.72 & - & - & - & & - & - \\
\hline & $3 \mathrm{~d} \times 2 \mathrm{y} 2$ & 1.99 & 1.99 & - & - & - & & - & - \\
\hline & $3 \mathrm{dz2}$ & 1.74 & 1.73 & - & - & - & & - & - \\
\hline & 3d(total) & 9.28 & 9.29 & - & - & - & & - & - \\
\hline & $4 s$ & 0.37 & 0.39 & _- & - & _ & & _- & - \\
\hline
\end{tabular}

Selected non-covalent interactions and corresponding second order energies are listed in Table 5. The presence of natural bond orbitals between metal centers and coordinated atoms according to NBO results indicate also the covalency of corresponding bonds in addition to coulomp type interactions except for the longest and the weakest two $\mathrm{Cu} 2-\mathrm{Cl} 1$ and $\mathrm{Cu} 2-\mathrm{Cl} 2$ bonds incorporating none of natural bond orbitals. Therefore, no remarkable contribution to the second order energy lowering comes from these weak covalent bonds as understood from Table 5 .

Table 5. Selected second orders energies from NBO analysis

\begin{tabular}{llc}
\hline Donor & Acceptor & $\mathbf{E}^{(\mathbf{2})}(\mathbf{k c a l} / \mathbf{m o l})$ \\
\hline Cu1-Cl1(BD) & Cu1-N6(BD*) & 0.70 \\
Cl1(LP) & Cu1-N1i(BD*) & 2.40 \\
Cl1(LP) & Cu2(LP*) & 5.66 \\
Cu2-Cl3(BD) & Cu2-N3(BD*) & 0.94 \\
Cu2-N3(BD) & N4-C8(BD*) & 3.10 \\
C6(LP) & N4-C7(BD*) & 180.48 \\
Cl2(LP) & $\mathrm{Cu} 2-C l 3\left(B^{*}\right)$ & 23.38 \\
Cu2-Cl3(BD) & Cu2-N3(BD) & 0.94 \\
Cl3(LP) & Cu2-Cl2(BD*) & 3.52 \\
Cu1-N1(BD) & $\mathrm{C} 1-H 1\left(B^{*}\right)$ & 0.54 \\
\hline
\end{tabular}

LP: a lone pair valence orbital, BD: 2-center bond orbital, BD*: 2-center antibond orbital, LP*: empty valence orbitals

The first 100 vertical excitations were analyzed by TD-DFT approach with B3LYP/LANL2DZ level of theory. Due to the large size of the system, the intra-ligand transitions under $298 \mathrm{~nm}$ were not calculated and not assigned. Only a single low intensity transition at $777 \mathrm{~nm}$ (A: 0.174) in the experimental spectrum (see Figure S2 in supporting information) is already assumed as an orbitally-forbidden d-d transition in view of electrostatic theory. From TD-DFT results, this transition can be assigned to the calculated one at $774 \mathrm{~nm}(f=0.0010)$ or the other at $716 \mathrm{~nm}(f=0.0032)$ both of which is qualitatively assig- ned as $\pi \rightarrow \pi / \mathrm{d}$ ( $\beta$-HOMO $\rightarrow \beta$-LUMO) transition by full population analysis of ground state MOs. Since none of transitions with non-zero oscillator strength in 600-800 $\mathrm{nm}$ region was found in TD-DFT aside from the aforementioned transitions (excitations under $298 \mathrm{~nm}$ not participate within 100 calculated ones and were not be able to involve because of scratch file size limitation of the program on 32 bit operating system).

\section{Conclusions}

Succesfully prepared a novel singly-chloro-bridged trinuclear monomeric $\left[\mathrm{Cu}_{3}(\mu-\mathrm{Cl})_{2} \mathrm{Cl}_{4}(1-\mathrm{Vim})_{6}\right]$ complex has been structurally characterized by $\mathrm{X}$-ray crystallograpy. The revealed $\mathrm{X}$-ray structure clearly shows that the molecule consists of two different copper(II) coordination sites, a distorted square-pyramidal terminal copper(II) ions and either distorted (Jahn-Teller elongated) octahedral or square-planar central copper(II) ion. Since copper(II) ion within significant amount of its complex compounds is mostly prone to give these coordination geometries. Interestingly, single chlorine atom in the trimer connects two copper(II) centers in the complex otherwise two chlorine atoms participate in bridging coordination in most of the other reported chlorine-bridged polynuclear species. ${ }^{34,35}$ The comprehensive computational studies were executed by the most efficient Hiybrid-density functional method (DFT-B3LYP) in a tolerable computation time despite the large size of the molecule. The data obtained from DFT, TD-DFT and NBO analysis succesfully represented the experimental trends.

\section{References}

1. M. Retegan, N. Cox, D. A. Pantazis, F. Neese, Inorg. Chem. 2014, 53, 11785-11793.

2. X. Y. Qiu, W. S. Liu, H. L. Zhu, Z. Anorg. Allg. Chem. 2007, 633, 1480-1484. 
3. J. Pasána, F. S. Delgadoa, Y. Rodrýìguez-Martýìna, M. Hernández-Molinaa, C. Ruiz-Péreza, J. Sanchizb, F. Lloretc, M. Julvec, Polyhedron 2003, 22, 2143-2153.

4. R. Vafazadeh, M. Alinaghi, A. C. Willis, A. Benvidi, Acta Chim. Slov. 2014, 61, 121-125.

5. R. Vafazadeh, N. Hasanzade, M. M. Heidari, A. C. Willis, Acta Chim. Slov. 2015, 62, 122-129.

6. A. Ozarowski, C. J. Calzado, R. P. Sharma, S. Kumar, J. Jezierska, C. Angeli, F. Spizzo, V. Ferretti, Inorg. Chem. 2015, 54, 11916-11934.

7. P. Haribabu, Y. P. Patil, K. H. Reddy, M. Nethaji, Transition Met. Chem. 2014, 39, 167-175.

8. E. Braña, C. Mendoza, P. Vitoria, J. González-Platas, S. Domínguez, C. Kremer, Inorg. Chim. Acta 2014, 417, 192200.

9. M. E. Ali, S. N. Datta, J. Mol. Struc.-Theochem. 2006, 775, 19-27.

10. A. Bencini, J. P. Costes, F. Dahan, A. Dupuis, J. Garcia-Tojal, D. Gatteschi, F. Totti, Inorg. Chim. Acta 2004, 357, 2150-2156.

11. Z. C. Hu, H. Y. Wei, Z. D. Chen, J. Mol. Struc.-Theochem. 2004, 668, 235-242.

12. E. Gungor, H. Kara, Inorg. Chim. Acta 2012, 384, 137-142.

13. J. Qian, M.-J. Xie, L. Feng, J.-L. Tian, J. Shang, Y. Zhang, S.-P. Yan, J. Coord. Chem. 2010, 63, 2239-2246.

14. S. Thakurta, P. Roy, G. Rosair, C. J. Gomez-Garcia, E. Garribba, S. Mitra, Polyhedron 2009, 28, 695-702.

15. T. Morawitz, M. Bolte, H. W. Lerner, M. Wagner, Z. Anorg. Allg. Chem. 2008, 634, 1409-1414.

16. H. Zhou, Z. H. Peng, Z. Q. Pan, D. C. Li, B. Liu, Z. Zhang, R. A. Chi, J. Mol. Struct. 2005, 743, 59-68.

17. W. Koch, M. C. Holthausen: A Chemist's Guide to Density Functional Theory 2th. Edit. Wiley-VCH, Weinheim 2001.

18. H. Chermette, Coordin. Chem. Rev. 1998, 178, 699-721.

19. J. J. Novoa, C. Sosa, J. Phys. Chem.-Us. 1995, 99, $15837-$ 15845.

20. P. M. Viruela, R. Viruela, E. Orti, J. L. Bredas, J. Am. Chem. Soc. 1997, 119, 1360-1369.

21. A. Altomare, M. C. Burla, M. Camalli, G. L. Cascarano, C. Giacovazzo, A. Guagliardi, A. G. G. Moliterni, G. Polidori, R. Spagna, J. Appl. Crystallogr. 1999, 32, 115-119.

22. G. M. Sheldrick, T. R. Schneider, Method Enzymol. 1997, 277, 319-343.

23. M. J. Frisch, G.W. Trucks, H. B. Schlegel, G. E. Scuseria, M. A. Robb, J. R. Cheeseman, J. A. Jr. Montgomery, T. Vreven, K. N. Kudin, J. C. Burant, J. M. Millam, S. S. Iyengar, J. To- masi, V. Barone, B. Mennucci, M. Cossi, G. Scalmani, N. Rega, G. A. Petersson, H. Nakatsuji, M. Hada, M. Ehara, K. Toyota, R. Fukuda, J. Hasegawa, M. Ishida, T. Nakajima, Y. Honda, O. Kitao, H. Nakai, M. Klene, X. Li, J. E. Knox, H. P. Hratchian, J. B. Cross, C. Adamo, J. Jaramillo, R. Gomperts, R. E. Stratmann, O. Yazyev, A. J. Austin, R. Cammi, C. Pomelli, J. W. Ochterski, P. Y. Ayala, K. Morokuma, G. A. Voth, P. Salvador, J. J. Dannenberg, V. G. Zakrzewski, S. Dapprich, A. D. Daniels, M. C. Strain, O. Farkas, D. K. Malick, A. D. Rabuck, K. Raghavachari, J. B. Foresman, J. V. Ortiz, Q. Cui, A. G. Baboul, S. Clifford, J. Cioslowski, B. B. Stefanov, G. Liu, A. Liashenko, P. Piskorz, I. Komaromi, R. L. Martin, D. J. Fox, T. Keith, M. A. Al-Laham, C. Y. Peng, A. Nanayakkara, M. Challacombe, P. M. W. Gill, B. Johnson, W. Chen, W. M. Wong, C. Gonzalez, J. A. Pople, Gaussian 03W, version 6.1 Gaussian Inc, Pittsburgh, 2003.

24. V. N. Nemykin, P. Basu, University of Minnesota Duluth and Duquesne University, 2001, 2003, 2005, VMOdes Program, Revision A 7.2.

25. D. R. ManPeru, R. Costa, M. G. Marquez, I. P. R. Moreira, F. Illas, J. Chem. Theory Comput. 2015, 11, 3650-3660.

26. M. R. Razali, A. Urbatsch, S. K. Langley, J. G. MacLellan, G. B. Deacon, B. Moubaraki, K. S. Murray, S. R. Batten, Aust. J. Chem. 2012, 65, 918-925

27. A. W. Addison, T. N. Rao, J. Reedijk, J. van Rijn, G. C. Verschoor, J. Chem. Soc., Dalton Trans. 1984, 1349-1356.

28. I. D. Brown, J. Appl. Crystallog. 1996, 29, 479-480.

29. I. D. Brown, The Chemical Bond In Inorganic Chemistry: The Bond Valence Model, Oxford Science Publications 2002.

30. A. Ray, D. Maiti, W. S. Sheldrick, H. Mayer-Figge, S. Mondal, M. Mukherjee, S. Gao, M. Ali, Inorg. Chim. Acta 2005, 358, 3471-3477.

31. G. A. van Albada, O. Roubeau, P. Gamez, H. Kooijman, A. L. Spek, J. Reedijk, Inorg. Chim. Acta 2004, 357, 45224527.

32. G. Seeber, B. M. Kariuki, L. Cronin, P. Kögerler, Polyhedron 2005, 24, 1651-1655.

33. B. Zurowska, J. Mrozinski, Z. Ciunik, Polyhedron 2007, 26, 3085-3091.

34. S. Choubey, S. Roy, S. Chattopadhayay, K. Bhar, J. Ribas, M. Monfort, B. K. Ghosh, Polyhedron 2015, 89, 39-44.

35. Y. Sikdar, R. Modak, D. Bose, S. Banerjee, D. Bieñko, W. Zierkiewicz, A. Bieñko, K. D. Saha, S. Goswami, Dalton Trans. 2015, 44, 8876-8888.

\section{Povzetek}

Pripravili smo nov trijedrni bakrov(II) kompleks $\left[\mathrm{Cu}_{3}(\mu-\mathrm{Cl})_{2} \mathrm{Cl}_{4}(1-\mathrm{Vim})_{6}\right]$ z enoveznimi 1-vinilimidazolnimi (1-Vim) in klorido ligandi in ga okarakterizirali z elementno analizo, termogravimetrijo (TGA, DTG, DTA), monokristalno rentgensko difrakcijo, TOF-MS in FT-IR spektroskopijo. Elektronske in strukturne lastnosti kompleksa smo nadalje proučevali z DFT/TD-DFT metodami. Pri izračunih smo uporabili hibridno metodo gostotnostnega funkcionala (B3LYP). Izračunane UV-Vis spektre na osnovi TD-DFT pristopa smo primerjali z eksperimentalnimi podatki. DFT izračuni so v skladu z eksperimentalnimi opažanji. 